\title{
Lumen
}

Selected Proceedings from the Canadian Society for Eighteenth-Century Studies

\section{Engraved Images, the Visualization of the Past, and Eighteenth-Century Universal History}

\section{Anne-Marie Link}

Volume 25, 2006

URI : https://id.erudit.org/iderudit/1012085ar

DOI : https://doi.org/10.7202/1012085ar

Aller au sommaire du numéro

Éditeur(s)

Canadian Society for Eighteenth-Century Studies / Société canadienne d'étude du dix-huitième siècle

ISSN

1209-3696 (imprimé)

1927-8284 (numérique)

Découvrir la revue

Citer cet article

Link, A.-M. (2006). Engraved Images, the Visualization of the Past, and Eighteenth-Century Universal History. Lumen, 25, 175-195.

https://doi.org/10.7202/1012085ar

Copyright (c) Canadian Society for Eighteenth-Century Studies / Sociéte canadienne d'étude du dix-huitième siècle, 2006
Ce document est protégé par la loi sur le droit d'auteur. L'utilisation des services d'Érudit (y compris la reproduction) est assujettie à sa politique d'utilisation que vous pouvez consulter en ligne.

https://apropos.erudit.org/fr/usagers/politique-dutilisation/ 


\section{Engraved Images, the Visualization of the Past, and Eighteenth-Century Universal History}

This article examines several engravings found in a 1744 German translation of the massive A Universal History from the Earliest Account of Time (published in instalments between 1736 and 1784). ${ }^{1}$ It explores these engravings in several ways: first, as part of the continuum of the mechanical reproduction of images, in this case, in the form of an image-text publication; second, from an interest in the roles these images may have played in the knowledge-making and dissemination processes of the concept of 'history' in Western Europe; and third, from the fact that the images are from a German adaptation of an English text, and thus provide an opportunity to consider their role in the context of translation. The engravings thus allow a focussed discussion of the role of the image in pan-European eighteenth-century history. As well, they draw attention to the Universal History itself as an important medium of image dissemination.

Although one of the most ambitious publishing projects of the eighteenth century, A Universal History from the Earliest Account of Time has not received much attention as an historiographic document, and none as disseminator of visual images. Guido Abbattista has extensively studied the work as a publishing phenomenon. ${ }^{2}$ He points out that the History

1 A Universal History, from the Earliest Account of Time, Compiled from Original Authors; and Illustrated with Maps, Cuts, Notes, Ec. (London: T. Osborne, 1736-1784).

2 Guido Abbattista, 'The Business of Paternoster Row: Towards a Publishing History of the Universal History (1736-1765),' Publishing History 17 (1985): 5-50 and Guido Abbattista, 'The English Universal History: Publishing, Authorship and Historiography in an European Project (1736-1790),' Storia, della Storiografia 39 (2001): 103-08. 
has suffered from a generally 'low and summary opinion' ${ }^{3}$ due mainly to the fact that universal history is perceived as conservative, concerned with 'ultimate origins, general patterns, and final goals that were inseparable from religious doctrines. ${ }^{\prime 4}$ And thus it was dismissed for its adherence to a Christian version of world history in which the deluge, the birth of Abraham, and Bishop Ussher's chronology remain unquestioned. ${ }^{5}$ It does not help that it came out as a serial publication, one produced by many authors, most of them of the 'unimportant' kind. However, some recent voices, like Abbatista, have begun to take notice of the History's specifically eighteenth-century role as a mediator of historical thought, suggesting a redefinition of its place in historical writing. These more recent commentators echo the original British editors of the work, who, in their 1729 publishing proposal, saw their publication as one peculiar to a new century. They claimed their work would eclipse all those other universal histories that 'seldom go further than the European nations'; in addition, the new aim of their work was to chronicle the 'discoveries and improvements made in history, chronology, and geography. ${ }^{\prime 6}$ Similarly, others have noted that the English publication and its various translations on the Continent might in fact have played a critical role in the 'widen[ing] [of] the [European] historical perspective to a global aspect ${ }^{\prime 7}$ and that it even 'oddly anticipat[es] the postmodern sensitivity to eurocentrism. ${ }^{\prime 8}$

The History' was a work of 'gigantic proportions, widely known and consulted throughout Europe in the eighteenth century. ${ }^{10}$ It provides an

3 Abbattista, 'The Business of Paternoster Row,' 6.

4 Donald Kelley, The Faces of History: Historical Inquiry from Herodotus to Herder (New Haven: Yale University Press, 1998), 211.

5 James Ussher (1581-1656) was Archbishop of Armagh, Primate of All Ireland, and Vice-Chancellor of Trinity College in Dublin. Through the study of biblical and historical texts, and astronomical calculations, he argued that the world was created in 4004 BCE. This chronology was included in the Great Edition of the English Bible in 1701 and came to be widely accepted as correct.

6 As quoted in D.R. Woolf, Reading History in Early Modern England (Cambridge: Cambridge University Press, 2000), 284.

7 Jörn Rüsen, Western Historical Thinking: An Intercultural Debate (New York and Oxford: Berghahn Books, 2002), 5.

8 Woolf, Reading History, 284.

9 I use this term inclusively to denote the original British version, as well as the subsequent translations and additions to it during the course of the eighteenth century. 
intriguing publication, joining tables, vignettes, frontispieces, maps, and engravings to a dense text. This presence of images in the literal context of a 'popular' eighteenth-century historical work commands attention, for it underlines the increasing role of the visual in the construction of historical narrative, ${ }^{11}$ as well as the phenomenon of increased accessibility of images throughout the course of the century. This accessibility was due to the fact that the images involved were printed and, to some extent, can be regarded as part of the technology of the mechanical reproduction that would culminate in the lithography, steel engraving, photography and, ultimately, film in the course of the following centuries. ${ }^{12}$ While the images found in the History were still of the engraved variety, predating mass production as associated with Walter Benjamin's theories, their presence in an encyclopedic serial publication ensured them an audience beyond what is usually attributed to eighteenth-century consumers of single engravings. In this case, the book was also to be viewed.

As Roger Chartier pointed out, the form of a printed work (image and text) cannot be separated from its meaning. ${ }^{13}$ In a similar fashion, the viewing of an image in a printed text cannot be divorced from the practice of reading itself, or perhaps more accurately, from the practice of using a book. By the eighteenth century, 'extensive' reading practices were replacing an older 'intensive' mode of reading, that is, the few volumes repeatedly read were being replaced by a greater number of publications and a subsequent development of practices such as 'skimming' or 'gutting. ${ }^{14}$ In the case of the text under consideration here, it is doubtful that many readers would have carefully read all of its volumes in sequence, or any of the volumes' four hundred or more pages (in the German edition) in its entirety. Yet, if one considers that the pages of these

10 Abbattista, 'The Business of Paternoster Row,' 6.

11 For a recent consideration of these issues in eighteenth century terms, see the special issue of Art History entitled Tracing Architecture: The Aesthetics of Antiquarianism, especially Dana Arnold, 'Facts or Fragments? Visual Histories in the Age of Mechanical Reproduction,' Art History 25.4 (2002): 450-68.

12 This trajectory, and its link to mass culture, is the subject of Walter Benjamin's well-known 'The Work of Art in the Age of Mechanical Reproduction,' in Illuminations, ed. Hannah Arendt, trans. Harry Zoh (London: Fontana, 1973), 211-44.

13 Roger Chartier, 'Representations of the Written Word,' in Forms and Meanings: Texts, Performances, and Audiences from Codex to Computer, ed. R. Chartier (Philadelphia: University of Pennsylvania Press, 1995), 6-24.

14 James Van Horn Melton, The Rise of the Public in Enlightenment Europe (Cambridge: Cambridge University Press, 2001), 86. 
volumes were interspersed with vignettes and full page engravings, an argument could be made for the usefulness of such images in supplying a reading system through which one can interpret the volumes, so that the organizing principle of A Universal History does not depend solely upon the syntax of the written text. Most importantly, these images changed the reader into a witness and observer who can now see the 'evidence' required for the construction of an historical record from the perspective of one who oversees that record. The images positioned the viewer in what Pierre Bourdieu has called the 'sovereign objectivist position ... where the social world presents itself as a spectacle seen from afar and above, as representation. ${ }^{15}$ The images thus position the reader/viewer in a way that is essentially different from linear reading.

Text and image were both regarded as equally important components of the publication by its originators. The title pages of the work advertise for the 'cuts, maps and illustrations' in the English version and for 'Kupfern und Karten' ('engravings and maps') in the German translation (Übersetzung der Algemeinen Welthistorie die in Engeland durch eine Gesellschaft von Gelehrten ausgefertiget worden). ${ }^{16}$ The German volumes were more richly illustrated than the English version. The German edition actually claimed to be a continuation, rather than a mere translation. While the British version aimed for a history 'like no [other] history [which] has hitherto appeared in any language,' comprising 'not only the history of all nations and countries, but of all religions, and religious ceremonies, of all arts and sciences, of the laws that have been any-where observed, of trade and navigation, and, in short, whatever has been invented for the use and convenience of the human race, ${ }^{\prime 17}$ the German continuation was to enhance and enlarge the project with additions and 'corrections,' most notably through the employment of 'many new engravings and maps' that would 'improve' the 'already excellent' English universal history. ${ }^{18}$ These 'improvements' included a range of

15 Pierre Bourdieu, The Logic of Practice (Stanford: Stanford University Press, 1990), 27.

16 Siegmund Jacob Baumgarten, Übersetzung der Algemeinen Welthistorie die in Engeland durch eine Gesellschaft von Gelehrten ausgefertiget worden. Erster Theil, Nebst den Anmerkungen der höllandischen Übersetzung; auch vielen neuen Kupfern und Karten. Genau durchgesehen und mit häufigen Anmerkungen vermeret (Halle: Johann Justinus Gebauer, 1744). The German series was published in Halle from 1744 to 1810.

17 A Universal History, 1747, xxxi.

18 Baumgarten, Algemeinen Welthistorie, 1746, 46-47. 
images of different types and subject matter, and they were positioned to engage the readers at differing points in the text.

Furthermore, these varying types of image not only provided an 'adornment' and enrichment of the text in terms of making it a more valuable object (although this, too, was part of their role), but also facilitated the mandate of the History, which was to render visible an historical chronology of the 'past,' in order to visualize a geographically available present, under the rubric of 'history.' The reader's entry into the volume would most certainly begin with the title page. The German edition consistently included the same vignette taking up a third of the page (Figures 1, 2, and 3). ${ }^{19}$ The framed view was to attract the reader's attention to its details. This was not found in the English volumes, ${ }^{20}$ which displayed instead a simple classical column. The more elaborate German vignette attests to that version's increased commitment to visual components.

The vignette provides a very perceptible depth in perspective that counteracts the surface and lateral motion of the eyes when involved in reading. The device of the banner crossing the top of the vignette provides a transition from reading to looking 'in depth' with words that both literally and rhetorically bind the vignette to the page. The words 'MORES HOMINUM MULTORUM VIDIT ET URBES. HOR' ['He observed the customs and cities of the world'] are taken from Horace's translation, in Ars Poetica, of the first line of Homer's Odyssey. In the context of the banner's placement above and in front of a scene representing 'other' lands, the quotation emphasizes both the practices of gaining insight through travel, much as Odysseus did. In this way, the banner underlines the claims of the volumes to show and to provide worldly insight to its European audience.

The vignette and its banner aptly condense categorizing under 'history' the cultures of the 'Other.' Jointly they also highlight the notion of world travel as a practice available to its European viewers, whose tour is solicited, if not requested. However, first of all, the viewer negotiates the dominant classical nude in the foreground, which acts as a marker of Western culture and its knowledge systems. The classical nude provides a paradigm for interpreting the events taking place in the background of the vignette. The nude is combined with the figure of Father

19 Figure 1 is taken from the 1744 volume and Figure 2 from the 1759 volume, with Figure 3 being a detail of Figure 2. Images by permission of The British Library.

20 The vignette was the work of the translator, Friedrich Rambach. 
Time flying through the sky, scythe in hand. Such a composite image is a commonplace of seventeenth-century frontispieces and emblem books, in which a female allegorical figure stands in front of a landscape surrounded by various objects, each with its own allegorical content. Although here the image is not truly an emblem, an allegorical reading is expected, especially for the female figure at the center of the picture. Her celestial halo indicates her most likely identification as that of 'Truth,' a central symbol of the Enlightenment. It would be found later, for instance in the frontispiece to Diderot's Encyclopédie. She also can be understood as planet Venus, which symbolized both the Morning and especially the Evening Star and its connotations of the West. In addition and most clearly, the figure is surrounded by instruments that relate to the visualization and representation of the 'world,' its exploration and its observation: those are represented by compasses, a painter's palette, a terrestrial globe, a telescope, and a map.

All of these instruments relate to geography and the planet's inhabitants. The linking of geography with history heralds the particular function of the other images in the text, which was to provide the viewer with representations of the past in the form of buildings, monuments, and other material artefacts associated with place. ${ }^{21}$ However, the vignette also differs from the rest of the images in that it provides the observer with a visualization of a geographically available present, encompassing all its inhabitants, from the small gesticulating figures encountering European men on the right to the pagan worshippers surrounding the temple on the left. Projection into the depth of the future also is suggested by the ship sailing away. Time and the heavens sanction this course from both sides of the vignette.

Spatio-temporal meaning can only be achieved through visual means. The passage of time indicated by the Father Time figure and the movement through space from foreground to background position the viewer as a witness, who can glance into the past, the present, and the future, thus establishing his position (most educated readers and collectors of serial publications were assumed to be male). Eurocentrism can be detected from such a structuring of meaning. The vignette offers the

21 I am influenced in this argument by the recent work of critical cultural geographers and others writing on the relationship between history, space, and place. See, for instance, Denis Cosgrove, 'Global Illumination and Enlightenment in the Geographies of Vincenzo Coronelli and Athanasius Kircher,' in Enlightenment Geographies, eds. C. Withers and D. Livingstone (Chicago University Press: Chicago, 2000), 33-66. 
traditional framing devices of seashells, foliage, and curlicues intertwined with Western measuring and recording instruments. The palm trees and pagan architecture pictured more deeply within the view creates a relationship between the European viewer and a distant world made available for observation and ordering.

Also, and I think this is an important point, it gives a visible form to the extension of the traditional and conservative explanations of universal history applied to new encounters and 'discoveries.' The History did not aim at being revolutionary in terms of overthrowing accepted paradigms; its aim was to educate a larger public about 'history' as it had been determined and to assess its direction in light of ongoing discoveries. As Daniel Woolf has recently and persuasively argued, a 'social circulation' of the past necessarily involves an infrastructure of 'lesser' works, ${ }^{22}$ and the History can perhaps most readily be identified as one of those. In addition, the Universal History offers a fascinating example of eighteenth-century assimilation of what Barbara Maria Stafford has rather dramatically termed an 'explosion of discontinuous and odd finds demanding representation. ${ }^{23}$ Stafford alludes to the representation of ongoing material historical 'discoveries' to be visually represented into a preexisting form - in this case, the grid of a universal, Biblically-based historical account.

The German translation of the History located 'discoveries' into a pre-existing pattern. One of its stated goals was to increase the readership for books of history - 'it is unarguable, that today the number of history lovers is not as commonly large as one might suppose in such enlightened times,' as Siegmund Jacob Baumgarten, the editor of the 1744 German volume wrote ${ }^{24}$ - and a way to do this was to convince the readers that the work contained the latest information of historical interest. The German History thus aimed to provide timely contributions and pictorial additions regarding the most current historical thinking, so that by 1767 Johann Christoph Gatterer could write that the work had

22 Daniel Woolf, The Social Circulation of the Past: English Historical Culture, 1500-1730 (Oxford: Oxford University Press, 2003).

23 Barbara Maria Stafford, Good Looking: Essays on the Virtue of Images (Cambridge, Mass.: MIT Press, 1996), 27.

24 '... so ist wol unstreitig, daß heut zu Tage die Menge der Liebhaber von Geschichten nicht aller Orten so gros sey, als man von so aufgeklärten Zeiten vermuten solte' (Baumgarten, Allgemeinen Welthistorie, 1744, 1.4). 
become 'a German original, not merely a translation. ${ }^{25}$ Readers were told that historical sources must go beyond an unquestioning reliance on texts, sacred or profane, to include a consideration of 'documents and monuments which commemorated events; pictures and inscriptions on medals, gems and buildings. ${ }^{26}$ In addition, the German history aimed to provide readers with current accounts of the world beyond Europe arising from new travel literatures, especially those describing the buildings of the ancients. Engravings and maps were to assist the understanding (Verständlichkeit) of these accounts, ${ }^{27}$ and deliver a more 'lively/vivid' (lebhaft) interpretation for the viewer, one not available from text alone. ${ }^{28}$

These notions of visible 'evidence' for the construction of historical narrative were carried out in the programme of images that followed the title-page vignette in the German volumes. This included a full-page engraving immediately opposite the title page and its vignette, as well as documentary images and maps interspersed throughout the volumes. The full page engravings, including the two examples shown here (FIGS. 4,5 ), were seen upon opening each volume. Their richness and accomplished technical execution must have encouraged the viewer to study the frontispiece before turning to the text itself. The engravings were linked visually to the vignette opposite through their similarity in composition: a framed view surrounding figures set before a deep landscape. Underneath each image, and incorporated into the frame, are the words 'Algemeine Welt-Historie von anbegin der Welt biß auf gegenwaertige Zeit' ('Universal World History, from the beginning of the world to the present time'), which emphasize the images' relation to the wide-ranging goals of the textual history they preface. The presence of revealed Biblical history is made manifest in the frames, which contain scenes of Old Testament events now made into pictures. These small pictures,

'. . e ein deutsches Original, nicht nur eine blosse Uebersetzung' (Johann Christoph Gatterer, ed., Allgemeine Welthistorie die in England durch eine Gesellschaft von Gelehrten ausgefertiget worden [Halle: Johann Justinus Gebauer, 1767], 2).

26 '... auch auf öffentliche Urkunden und Denkmale geschehener Begebenheiten, Bilder und Aufschriften von Münzen, Steinen und Gebaüden' (Gatterer, Allgemeine Welthistorie, 11).

27 Gatterer, Allgemeine Welthistorie, 11.

28 'Man pflegt endlich auch historischen Werken sehr gerne Kupferstiche von Siegeln, Münzen, Denkmälern u.d.gl. anzufügen ... weil man glaubt, da ... dergleichen Kupferstiche für die erzählte Sache lebhafter, als blosse Worde, reden' (Gatterer, Allgemeine Welthistorie, 36). 
referring to an established textual source for historical 'truth,' are meant to contextualize the larger central view. The latter is composed of foreground figures, all allegorical or biblical. They are once again surrounded by the items of technology suggesting European observation - compasses, maps, and drawings. Figure 4 also displays for the viewer a number of material objects related to learning: books, a cosmological map, and a terrestrial map in the process of being measured by a compass-wielding putto in the foreground. In addition, the practices of invention, mathematics, theory, and measurement are represented allegorically by female figures, one with wings on her head, the other carrying a set of compasses. The woman holding a mirror may represent 'perfect work' or 'prudence,' according to Ripa's Iconologia, or 'critical knowledge' according to Jesuitical interpretations - all allegories point to the power of Western observation and intellect, its capability of ordering and understanding the past as represented materially in the background obelisk and pyramid.

Similarly, in the example of the second frontispiece (Figure 5), the eye once again encounters a group of foreground figures before moving on into the background. Here, several putti, a rabbi, a mapmaker, a map of the Ten Tribes of Israel, and an armoured warrior provide a fusion, in a tightly packed visual composite of Western classical culture, biblical 'truth,' and European might. Several other of the frontispieces refer to the lost Ten Tribes of Israel, visually emphasizing a plausible biblicallybased explanation for the confusing variety of newly discovered peoples with which the History has to contend. ${ }^{29}$ Material remains of the past linger in the background, such as the Tower of Babel. ${ }^{30}$

When the viewer confronts the double frames of both pages with the borders formed by the ornate illusionistic 'frames' themselves, the viewer is directed, fully enlightened, into the historical past. Here, buildings and monuments represent the 'past,' an historical world 'writ-

29 For a recent account of the myth of the Ten Tribes and its relation to explanations of racial variety, see Tudor Parfitt, The Lost Tribes of Israel (London: Weidenfeld and Nicolson, 2002).

30 The existence of the Tower of Babel was generally accepted at this time, particularly as a result of Athanasius Kircher whose illustrated 1679 Turis Babel was well known. See Daniel Stolzenberg, 'Kircher Among the Ruins: Esoteric Knowledge and Universal History' in The Great Act of Knowing: The Baroque Encyclopedia of Athansius Kircher, ed. Daniel Stolzenberg (Stanford: Stanford University Libraries, 2001), 127-39, for an interesting discussion of Kircher and the tradition of universal history in the seventeenth century. 
ten' through the evidence of material remains. While the written text is ordered in terms of a chronological movement from ancient to more recent civilizations, the images provide a balancing spatial and temporal order, with the eye moving again from a proposed allegorical and biblical reality to a material 'reality' deeper within the image. As noted by Stephen Bann in his study of historical culture of the later eighteenth and early nineteenth centuries, 'visual examples' can engage a spectator/reader in a more 'participatory' way than text. ${ }^{31}$ From a foreground steeped in familiar cultural symbols, the reader is invited into a background of 'realistic' monuments, transporting him as a physical participant in the movement from an emblematic and eternal order to the application of that order to new visual manifestations. The reader is thus prepared for the prefatory essay by Siegmund Jacob Baumgarten and the rest of the images inserted at varying points in the text.

Baumgarten was a professor of theology at Halle, and he was also associated with a new 'wissenschaftlich' ('scientific') movement in scholarship. ${ }^{32}$ In his 1744 essay, he advocated a change to the idea of historical 'evidence,' challenging a reliance on text alone in his call for the study of 'monuments ... pictures, inscriptions' when searching for historical 'truth.' He admitted that even though the general reader might look to history mainly for moral instruction and a 'heilsamen Zeitvertreib' ('a healthy pass-time'), both amateur and scholarly reader should be interested in the study of the places and monuments uncovered in the 'neueste Reisebeschreibungen' ('newest travel accounts'). ${ }^{33}$ For this reason, the German volumes would add 'many maps and engravings ... which not only provide a pleasant decoration to the work, but also promote the understanding of treatises and discussions. ${ }^{34}$

Chief among the 'improving' pictorial additions of the first German volumes (both in the sense of improving on the original British volumes and in the sense of improving the understanding) were ten engravings of Egypt. These were designed to bring to the foreground the distant

31 Stephen Bann, Romanticism and the Rise of History (New York: Twayne, 1995), xiii.

32 Martin Schloemann, System und Geschichte in der Theologie des Übergangs zum Neuprotestantismus (Göttingen: Vandenhoeck \& Ruprecht, 1974). Siegmund Jacob was the brother of the famous Alexander Gottfried Baumgarten.

33 Baumgarten, Algemeinen Welthistorie, 23.

34 '... haeufigen Karten und Kupfer ... die dem Werke nicht nur zur angenemen Zierde gereichen, sondern die Verstaendlichkeit mancher Abhandlungen nicht wenig befoerdern' (Baumgarten, Algemeinen Welthistorie, 47). 
monuments seen in the background of the frontispiece engravings. They appeared in their immediacy, free from framing devices, and unaccompanied by allegorical or biblical figures. Their documentary form was meant to produce what Baumgarten identified as the chief goal of history, 'an established account of events. ${ }^{35}$ Most of the German volumes' Egyptian engravings were copies taken from Richard Pococke's A Description of the East and of Some Other Countries and Benoît de Maillet's Description de l'Egypte. ${ }^{36}$ Both were recent publications (Pococke's in 1742 and de Maillet's in 1735), whose images had not circulated beyond scholarly or antiquarian viewers. The German History would thus ensure a larger audience, even if it was a more popular one, seeking not only instruction but also entertainment.

The images fell into two types: one, an unadorned documentary style, and the other, a scenic type providing a 'view.' The first type (Figure 6) consisted of sectioned views and scales of measurement that give these images a dissected 'hard evidence' quality. Thus, the cross-section images of the pyramids at Saqqara, which, as the History pointed out, had until then suffered from a contradictory and confusing range of measurements, could then be 'truly' seen. ${ }^{37}$ The cross-sections provide the kind of 'scientific' precision that the narration of history was beginning to demand, and the mechanics of the image have changed to accommodate this style of looking. Instead of being a 'scene' into which one enters, moving 'naturally' from fore- to mid- to background, the pyramids are presented in a manner reminiscent of anatomical or botanical cross-sections, that is, as a representation produced by the expert understanding of one who knows the 'truth' in a way not apparent to the casual eye. The apparatus of measuring scales and additional details 'floating' beside the cross-sections negate the 'picturing' effect of the image as a spatial box, but increase its claims to a total visualization of all that is necessary. Reliability and objectivity are associated with these types of images, being devoid of any 'eye pleasing' elements. Such cross-sections are supposed to reveal only the 'facts.' Neither do they situate a viewer at any one point; they exist as eternally valid images: the presence or Welthistorie, 7).

36 Richard Pococke, A Description of the East and of Some Other Countries. Volume the First, Observations on Egypt (London: W. Bowyer, 1743) and Benoît de Maillet, Description de l'Égypte: contenant plusieurs remarques cuneuses sur la géographie ancienne et moderne (Paris: Chez le Genneau et J. Rollin, fils, 1735).

37 Baumgarten, Algemeinen Welthistorie, 1744, 391-92. 
absence of a viewer is immaterial. In fact, those views are not materially accessible as no one has seen a sectioned pyramid to date. The 'simplicity' of the image functioned as a marker of objective truth.

The pyramids are seen again when presented in situ in the desert (Figure 7), with the Sphinx in the centre and repoussoir spear-carrying figures in the immediate foreground. Here, a different space necessitates a different gaze, activating once again the subject of the individual viewer, who sees the space and its objects from behind and somewhat above the foreground figures, thus assuming the position of the delineator/knower of the scene. The production of what is clearly a 'picture,' in which the Sphinx has been chosen for the middle of the composition, is enhanced by composition devices which direct the eye, from the repoussoir figures who literally point into the scene, to the scale-producing small figures besides the enormous pyramids. The centrality of the viewer is thus acknowledged, as these devices only work when a central and stationary viewer is accounted for. The 'picture' quality is clearly important and may explain why Pococke gave the Sphinx a nose, allowing the viewer from the present to gaze into an unblemished past. ${ }^{38}$

The images, consistently placed on the page opposite to their written descriptions, emphasized the text that echoed its visual impact. In many places, the text appealed directly to the reader's visual imagination, calling, for instance, for the reader to imagine 'four equal sides to the pyramid' (since the engraving shows, by the necessity of a picture organized around a single viewpoint, only two of the sides), an act which, along with the measurements provided, will ensure its 'actual' form. ${ }^{39}$ The German History, as an 'archive of truth' (as the 1767 volume put it) ${ }^{40}$ made much of the 'actuality' of its historical account and relied heavily on a new emphasis on the empirical evidence gained through sight. In this, the editor considered the illustrated volumes an important

38 The Sphinx was already missing its nose when Pococke saw it in 1735 and was represented without one in Frederick Lewis Norden's (1708-1742) drawing of a noseless Sphinx in 1737. Frederick Lewis (Ludvig) Norden, Captain Norden's Travels in Egypt and Nubia, With Improvements on the Original ... Illustrated with One Hundred and Sixty Four Large Folio Copper Plates, Being the Originals Engraved by the Celebrated Marc Tuscher of Nuremberg (London: Lockyer Davis and Charles Reymers, 1757).

39 'Wenn wir uns nun auf die Seiten der Grundlage . . . vier gleichseitige Dreiecke vorstellen ... so bekommen wir in richtiges Bild von den wahren Ausmessungen und der eigentlichen Gestalt dieser Spitzseule' (Baumgarten, Algemeine Welthistorie, 1744, 392).

40 'ein Archiv der Wahrheit' (Gatterer, Allgemeine Welthistorie, 1767, 44). 
contribution to history in general, so that by 1767 he could write that 'one of the most important parts of the historical art is evidence' and that this 'evidence' was defined as that which is 'Augenscheinlich,' that is, apparent to the eye and to the mind. ${ }^{41} \mathrm{~A}$ history was to 'awake in the reader an imaginary presence of events... so that the reader becomes at the same time a viewer. ${ }^{.42}$ While Johann Christoph Gatterer, the historian who wrote these words, expected this 'imaginary present' to be produced by a lively narrative style, he also maintained that it was a task that was made infinitely easier by the addition of images.

As identified by Gatterer, in the recognition and promotion of this critical shift from reader to viewer resides the importance of the images of the History, a shift anchoring this publication into the eighteenth century. By positioning the viewer as a witness and a participant in 'history,' the images contributed to the knowing position of the European eighteenth century itself. Foucault's well-known triad of knowledge-power-subject was a narrator of that history and the kernel of its ordering functions. The people who purchased the universal history were thus not to be perturbed by such claims as Benoit de Maillet's (if they knew them at all), who, in his textual account of Egypt, claimed that biblical chronology could not be correct, ${ }^{43}$ for they had seen just the opposite: Old Testament accounts and pyramids together in one unified view. It is the ability of the image, at one glance, to conflate the allegorical and the material, the old and the new, the eye-witnessed and the imagined that made this view sustainable. It was not possible textually. The engravings gave the viewer a place of knowing, from which the spaces and places of the world could be accommodated into an historical account that had long had meaning for the European West. As Barbara Maria Stafford has so often pointed out, the imagistic world is not identical with the textual world, and needs its own attention; as well, she points out that the eighteenth-century visual world needs to be recognized as part of the continuum of the 'visualization of knowledge' made possible by 'technology's ever-advancing power to make the invisible visible. ${ }^{44}$ By making 'history' visible, the engraved image placed the

41 Gatterer, Allgemeine Welthistorie , 1767, 3.

42 'Man erwecke bey dem Leser ideale Gegenwart der Begebenheiten ... daß der Leser gliechsam zum Zuschauer werde' (Gatterer, Allgemeine Welthistorie, 1767, 11).

43 Marie Louise and Jean Dufrenoy, 'Benoit de Maillet as Precursor to the Theory of Evolution,' Archives internationale d'histoire des science 7 (1954), 161-67.

44 Stafford, Good Looking, 22. 
European reader/viewer into a new global present from which both past and future could be comfortably surveyed.

\section{ANNE-MARIE LINK}

University of Alberta 


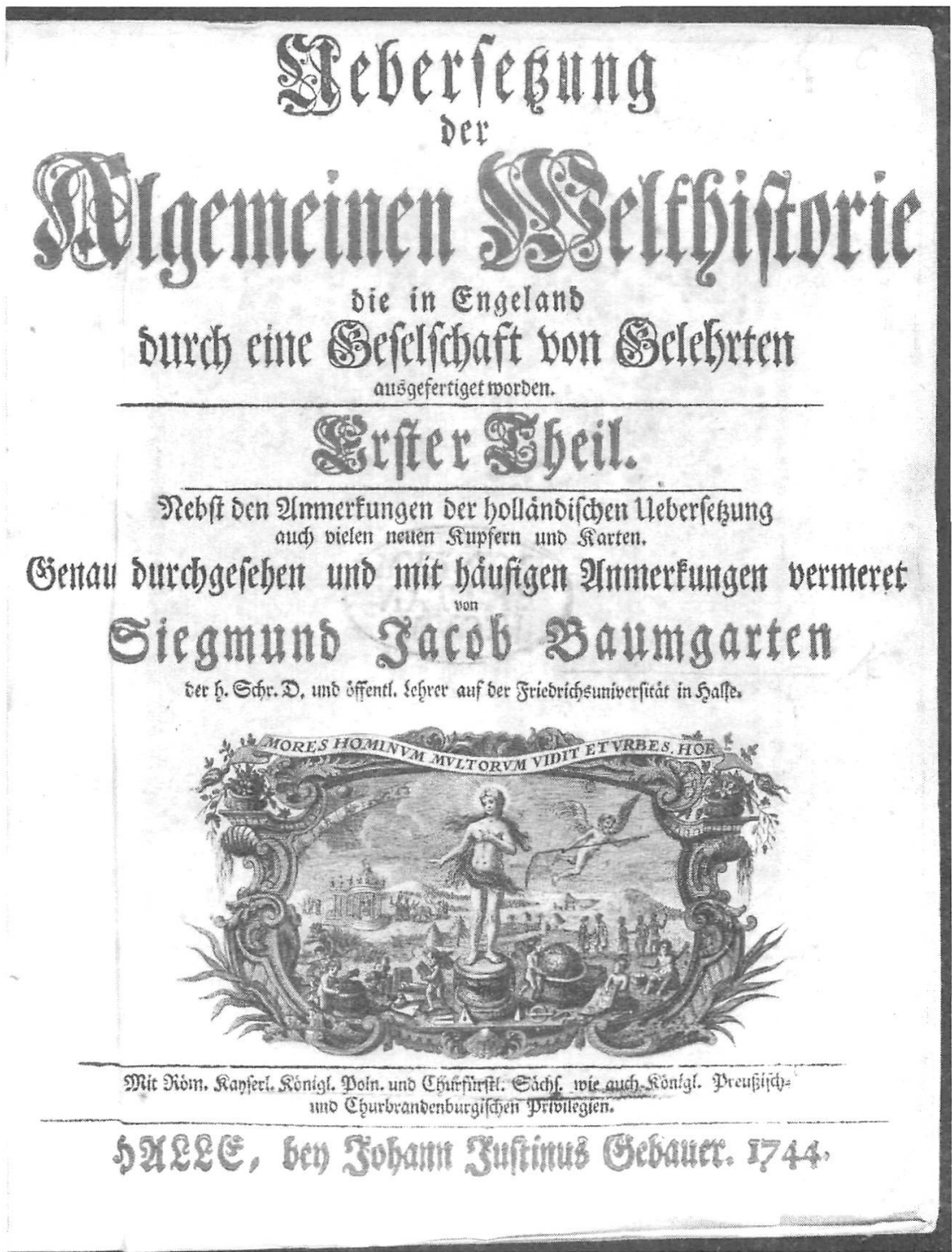

Figure 1. British Library Reproductions 897 f1 TP $004 \mathrm{M} 00943$ 


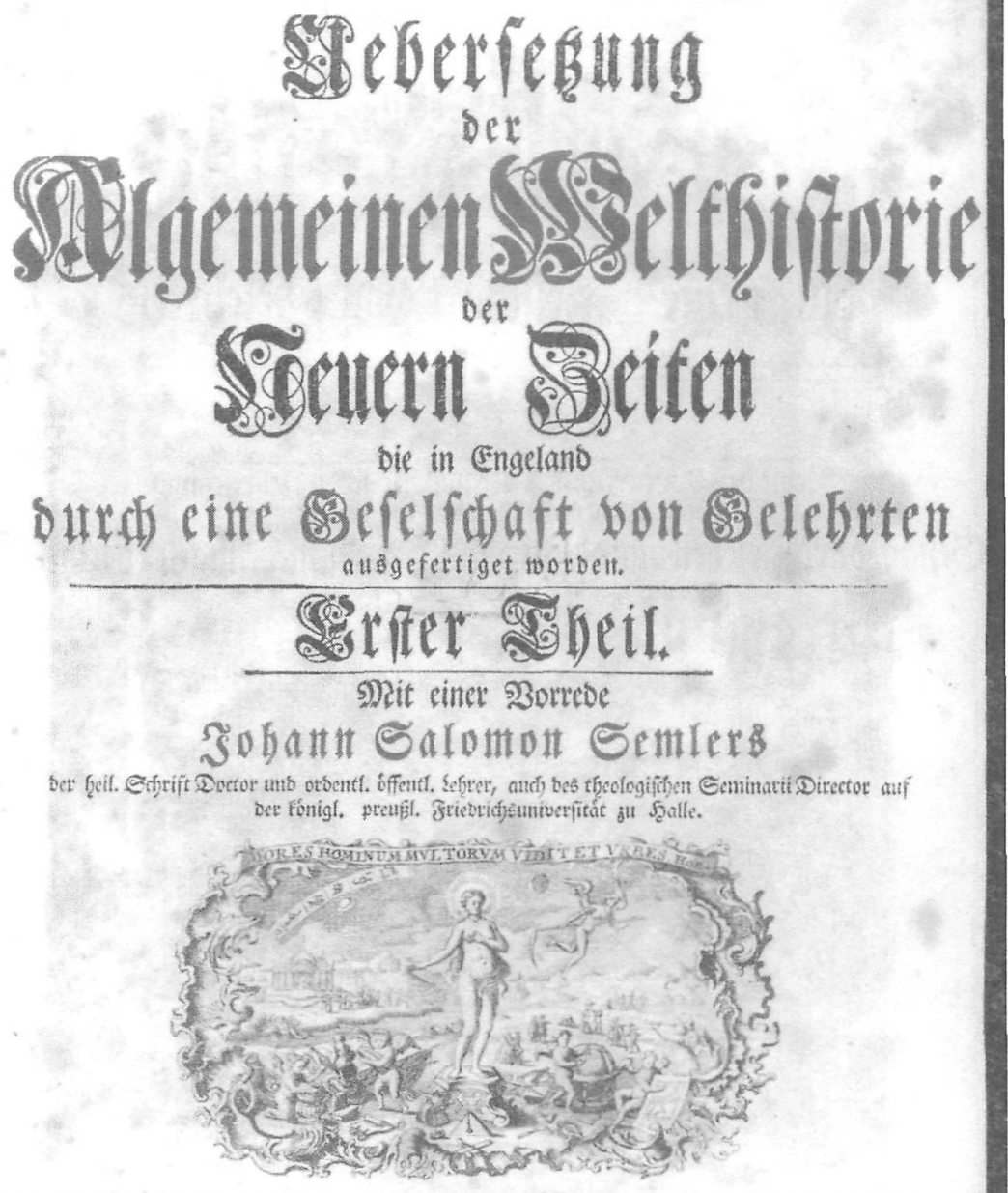

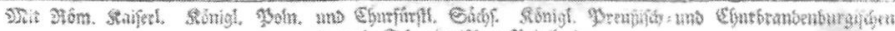

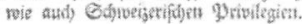

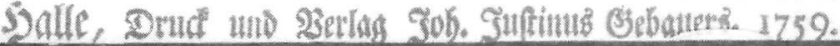

Figure 2. British Library Reproductions 897f1() TP $04 \mathrm{M} 00943$ 


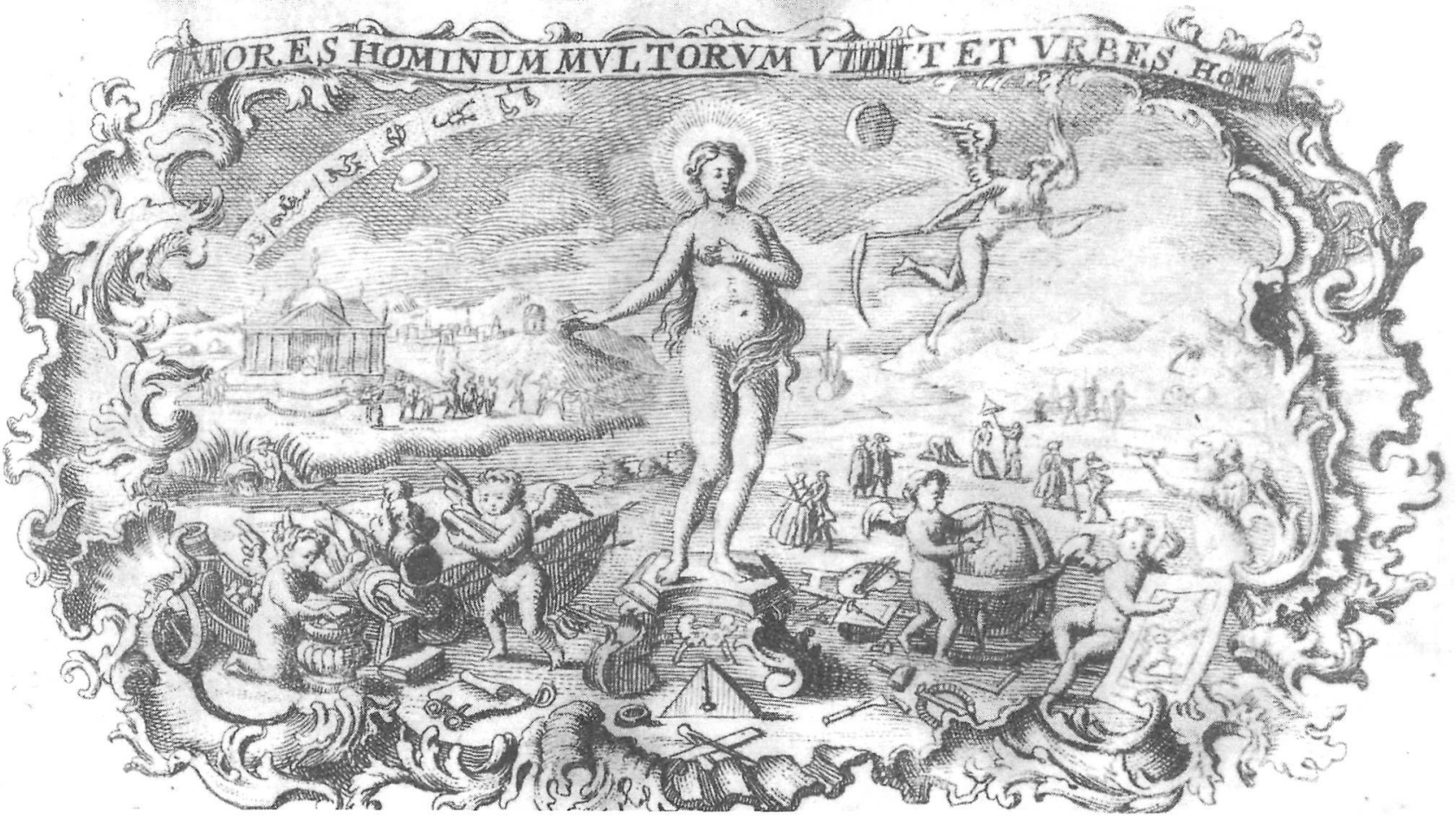




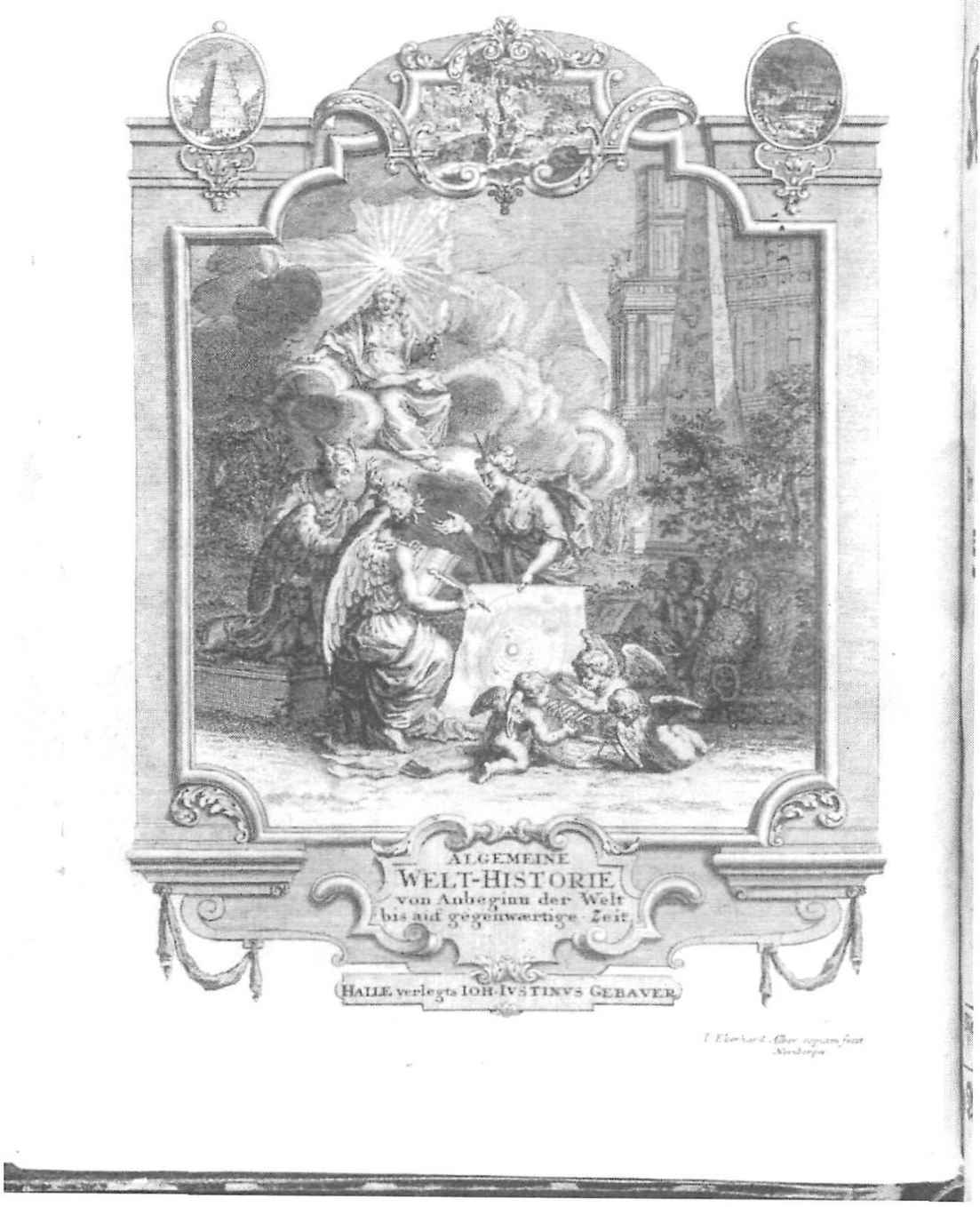

Figure 4. British Library Reproductions 897f1 FP 04 M00943 


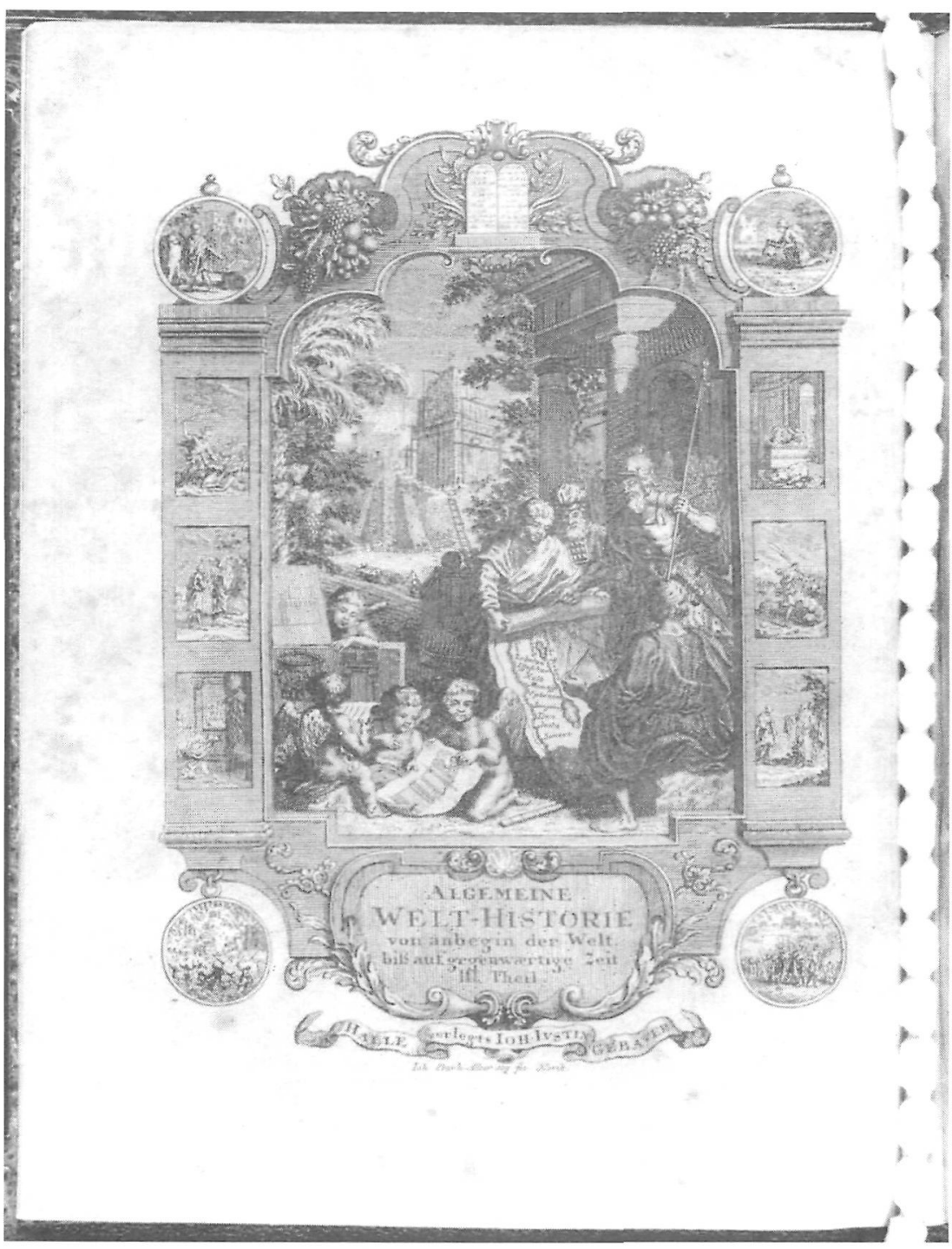

Figure 5. British Library Reproductions 897.f2 F/P 02A00726P 


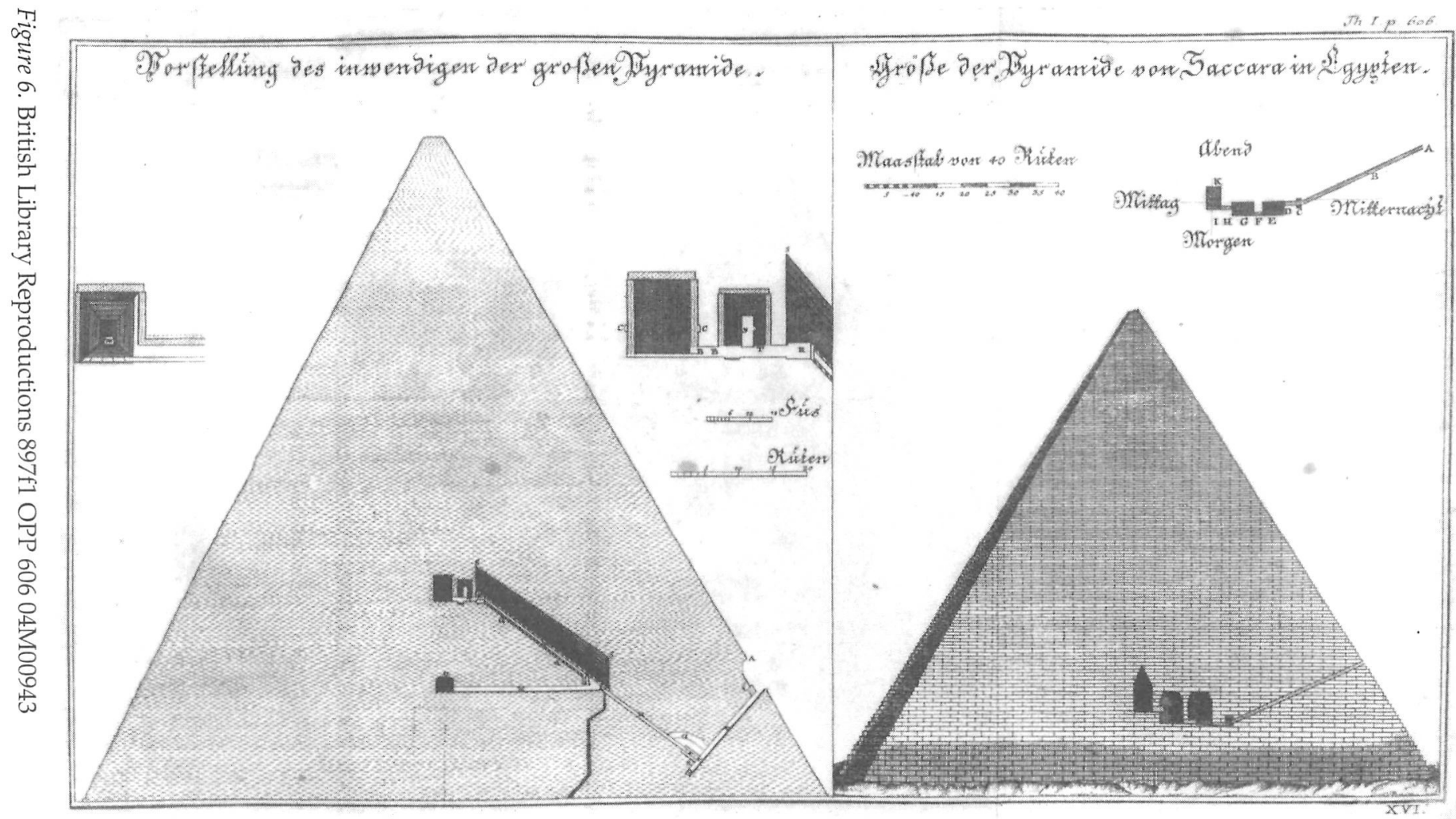




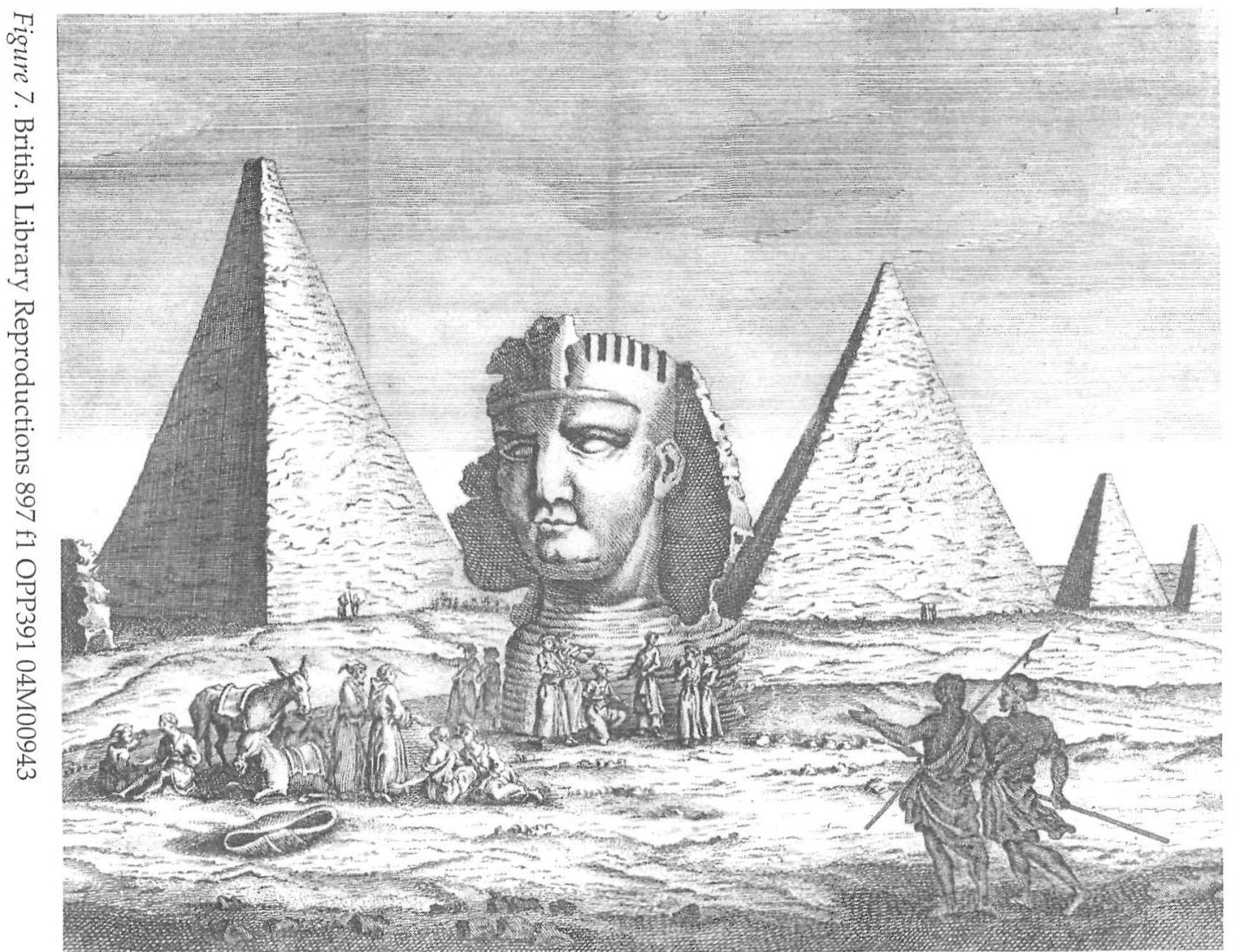

